\title{
GRANDE SERTÃO: VEREDAS E FORMAÇÃO \\ BRASILEIRA
}

\section{GRANDE SERTÃO: VEREDAS AND BRAZILIAN FORMATION}

Danielle Corpas ${ }^{*}$

RESUMO: Desde meados da década de 1990, ganhou espaço na recepção crítica brasileira de Grande sertão: veredas o questionamento a respeito do sentido para a formação nacional implicado na configuração do romance. $\mathrm{O}$ artigo confronta proposições surgidas nesse debate em curso.

PALAVRAS-CHAVE: Guimarães Rosa, Grande sertão: veredas, literatura brasileira, literatura e sociedade, crítica literária.

ABSTRACT: Since mid-1990's, brazilian critics have been exploring the meanings concerning national formation that might be implied in Grande sertão: Veredas. The present article compares diferent point of views on the subject, an argument still taking place in debate.

KEY WORDS: Guimarães Rosa, The Devil to Pay in the Backlands, Grande sertão: veredas, Brazilian literature, literature and society, literary criticism.

\footnotetext{
* Universidade Federal do Rio de Janeiro. Doutora em Teoria da Literatura pela UFRJ. Professora visitante do Departamento de Ciência da Literatura da UFRJ. Email: daniellecorpas@utopos. com.br.
} 



\section{GRANDE SERTÃO: VEREDAS E FORMAÇÃO BRASILEIRA}

Mesmo sem muito distanciamento, já podemos reconhecer o decênio de 1994 a 2004 como um período divisor de águas na fortuna crítica de Grande sertão: veredas. Desde o início dos anos 70, quando saíram Jagunços mineiros de Cláudio a Guimarães Rosa (CANDIDO, 2004), As formas do falso (GALVÃO, 1986) e A epopéia de Riobaldo (DACANAL, 1988) - cujas publicações originais datam de 1970, 1972 e 1973, respectivamente -, não se via tanto esforço de reflexão para esclarecer relações entre dinâmicas específicas da vida no país e a forma singular do romance de Rosa. Basta percorrer as bibliografias dos trabalhos mais recentes para constatar o silêncio de uns vinte anos sobre o assunto. A retomada se deu na segunda metade da década de 90 com os artigos publicados por Davi Arrigucci Jr., Willi Bolle, José Antônio Pasta Jr. e Heloísa Starling. Esta também assina o primeiro escrito longo da nova safra, a tese de doutoramento em Ciência Política Lembranças do Brasil: teoria política, história e ficção em Grande sertão: veredas, lançada em 1999. Dois outros resultados finais de pesquisas mais extensas vieram a público em 2004: O Brasil de Rosa: mito e história no universo rosiano: o amor e o poder, de Luiz Roncari, e grandesertão.br: o romance de formação do Brasil, de Willi Bolle.

São ensaios e teses integrantes de um conjunto no qual é consenso que Grande sertão: veredas põe em cena problemas cruciais da história do país; que a trajetória de Riobaldo, a situação de seu relato, o tratamento da 
linguagem e a configuração peculiar da narrativa, cheia de carga simbólica e mítica, têm a ver com processos constitutivos de nossa sociedade, decisivos na definição de sua feição moderna. As muitas divergências entre os intérpretes convergem também para esse núcleo crítico: de que caráter se reveste a formação brasileira figurada no romance? Para que sentido aponta a gênese de padrões de organização social, política, econômica e cultural que se vê formalizada na ficção?

Publicado no primeiro ano do governo Kubitschek, assim como Corpo de baile, Grande sertão: veredas foi redigido após a viagem pelo sertão mineiro que Guimarães Rosa realizou em maio de 1952, acompanhando um grupo de vaqueiros. As observações sobre a fala, os costumes, a fauna e a flora locais, que trouxe anotadas em cadernetas, toda aquela experiência somou-se às que já obtivera em duas ocasiões anteriores - o período em que atuou como médico no interior de Minas Gerais e uma outra excursão pela região feita em dezembro de 1945. A datação desses episódios biográficos, durante os quais o escritor se alimentou, na fonte, da matéria sertaneja que informa seu universo ficcional, corrobora uma constatação de Luiz Roncari: o romance de 1956 integra um projeto literário que vai se encorpando durante o período do desenvolvimentismo getulista, tendo começado a evidenciar-se em 1937, com a primeira versão de Sagarana (2004, p. 13). Esse itinerário artístico, de poucas estações e longa duração, que tem em Grande sertão: veredas um ponto de chegada, transcorre em época de mudanças significativas no país - sucessivos sobressaltos no âmbito da política institucional (da Revolução de 1930 ao fim do Estado Novo), alterações no andamento da economia (com a crescente guinada rumo à modernização industrial), e a conseqüente emergência de novos parâmetros para as relações sociais.

Tensões e expectativas acumuladas a cada momento também estavam no horizonte de Guimarães Rosa, assim como no de intelectuais como Gilberto Freyre, Sérgio Buarque de Holanda, Caio Prado Jr., Raymundo Faoro, Celso Furtado e Antonio Candido. Cada um no seu campo, entre os anos 30 e 50, investigou processos decisivos para a configuração da vida social, política, econômica ou literária no Brasil, produzindo obras hoje clássicas ${ }^{1}$.

${ }^{1}$ Refiro-me a Casa grande e senzala (Gilberto Freyre, 1933), Raízes do Brasil (Sérgio Buarque de Holanda, 1936), Formação do Brasil contemporâneo (Caio Prado Jr., 1942), Os donos do poder: formação do patronato político brasileiro (Raymundo Faoro, 1958), Formação econômica do Brasil (Celso Furtado, 1959), e Formação da literatura brasileira (Antonio Candido, 1959). 
Em comum, tinham o foco na formação nacional - orientação da pesquisa de fundamentos e posicionamento em prol de um projeto de nação. As propostas para o país, muitas vezes subliminares à análise do passado, não são idênticas, mas o empenho é de grau equivalente. Formação é uma palavra-chave, expressão de força motriz no ânimo desses contemporâneos das primeiras obras de Rosa. O fato de a recepção crítica de Grande sertão: veredas voltar-se há mais de uma década para a questão da formação nacional - e num tempo em que a idéia de nação desempenha funções distintas daquelas que circulavam aqui há meio século - convida a refletir sobre o nexo entre forma literária, formulações críticas e experiência brasileira.

São bastante díspares os juízos recentes que incidem concomitantemente sobre o romance e sobre o Brasil. Para Heloísa Starling, é "como se Guimarães Rosa desejasse indicar que continua truncada, na formação nacional brasileira, a oportunidade política da emancipação e o sentimento de comunidade" (1999, p. 18); o relato de Riobaldo parece-lhe "uma história de fim de mundo sobre uma terra que, se já perdeu o tempo, ainda conserva a esperança de reconhecer passagens em meio às ruínas de sua história" (1996, p. 16). Segundo Willi Bolle, o romance trata do "sério entrave para a plena emancipação do país" que é a "falta de diálogo social" - "A dificuldade da formação de uma cidadania para todos é expressa também através da forma de um texto difícil", que funciona como laboratório da conversa entre os donos do poder e o povo, assim "fazendo entrever amplas possibilidades históricas de transformação” (2004, p. 17-45). Luiz Roncari vê nas três primeiras obras de ficção do escritor configurar-se uma visão de nossa formação político-social traçada do ponto de vista do "conservadorismo crítico", que propõe "a harmonização das forças contrárias, como modo de solução" pautado sobretudo pelo ideário de Alberto Torres, Alceu Amoroso Lima e Oliveira Vianna (2004, p. 20-24). José Antônio Pasta Jr. detecta no romance de Rosa a "má infinidade" própria da "contradição insolúvel e central que singulariza o Brasil"; o "regime peculiar ao livro - o da formação como supressão" atualiza "o modo de produção que diz respeito à nossa formação histórica”, na qual não se superou a "junção contraditória de formas de relações interpessoais e sociais que supõem a independência ou a autonomia dos indivíduos e sua dependência pessoal direta" (1999, p. 67-70).

No mesmo momento em que preocupações dessa ordem começavam a receber ênfase nos trabalhos de interpretação do romance, Paulo Arantes e Roberto Schwarz, comentando a Formação da literatura brasileira de 
Antonio Candido à distância de quatro décadas, punham sob a ótica das circunstâncias contemporâneas a idéia de formação. Levantaram problemas em torno deste tópico que vão nos ajudar a acompanhar os sentidos propostos pela crítica atual para a versão rosiana da formação brasileira. Os ensaios Providências de um crítico na periferia do capitalismo (ARANTES, 1997) e, mais explicitamente, Os sete fôlegos de um livro (SCHWARZ, 1999) remetem a uma questão de fundo inescapável quando se trata de proposições que recorram hoje à noção em pauta: o descompasso entre, de um lado, as expectativas "formativas" de integração da sociedade brasileira num todo satisfatório em termos econômicos e sociais e, de outro lado, as condições objetivas, de alcance planetário, definidas pela modernização capitalista ao longo da segunda metade do século XX.

Paulo Arantes chama atenção para o fato de que a noção de formação é "a um tempo descritiva e normativa". Como aqueles intérpretes do Brasil que, entre os anos 30 e 50, haviam sistematizado linhas evolutivas na experiência social, econômica ou política locais, Candido ajustara o foco historiográfico para detectar processos contínuos em nossa vida literária. Considerando essa constelação intelectual, Arantes formula um problema que depois Roberto Schwarz iria pormenorizar. No passado, todas essas investigações dos rumos seguidos pela história nacional em diversos âmbitos eram mobilizadas por um ideal de formação (definido pela "direção do ideal europeu de civilização relativamente integrada"). Mas há uma "diferença crucial, ligeira dissonância" entre a efetiva "formação de um sistema cultural" (o sistema literário já em funcionamento quando historiado por Candido na obra de 1959), e o "histórico das expectativas sociais que sempre acompanharam as anatomias clássicas da malformação brasileira" (1997, p. 12-13).

Numa palavra, o Brasil não dera certo, ia mesmo muito mal, porém sem comprometer a Formação de Antonio Candido, pois nosso sistema literário não só se formara como até funcionava razoavelmente bem. Vantagens de uma dimensão que goza de relativa independência? Sem dúvida, e por isso mesmo país errado e cultura viva podem até certo ponto conviver sem danos mútuos irreparáveis. (ARANTES, 1997, p. 13).

Dois anos mais tarde, Schwarz glosou o mote de Arantes - país errado e cultura viva. Retomando a comparação entre o livro de Candido e os en- 
saios de formação produzidos no campo das ciências sociais e da economia, salientou que Sérgio Buarque de Holanda, Caio Prado Jr. e Celso Furtado supunham a possibilidade de uma conclusão satisfatória para o percurso socioeconômico do país num então futuro próximo, enquanto Candido lidou com o sistema literário já formado "mais ou menos à volta de 1870, antes da abolição da escravatura". Ou seja, o "grau considerável de organização mental" atingido pela elite letrada, capaz de produzir obras de alto nível, não implicou nem dependeu de elevação equivalente do "grau de civilidade" no corpo social. Foram processos que seguiram ritmos distintos. Nessa medida, o tratado de Candido fica como esclarecedora "descrição do progresso à brasileira, com acumulação muito considerável no plano da elite, e sem maior transformação das iniqüidades coloniais". Formação da literatura brasileira funciona como pedra de toque tanto para as expectativas dos pensadores do Brasil imediatamente precedentes ou contemporâneos ao livro, quanto para o presente: "É como se nos dissesse que de fato ocorreu um processo formativo no Brasil e que houve esferas - no caso, a literária - que se completaram de modo muitas vezes até admiráveis, sem que por isso o conjunto esteja em vias de se integrar". (1999, p. 55).

Uma vez que o andamento da vida política e o modo de inserção do país no contexto da economia mundializada não apontam para uma mudança de rumo, para a ocorrência de uma virada decisiva no sentido da efetivação de um todo social coeso, o ideal de formação solicita avaliação muito cuidadosa ${ }^{2}$. Diante do quadro no qual tudo indica ser impossível que "nossa sociedade venha a se reproduzir de maneira consistente", Roberto Schwarz pergunta: "como fica a própria idéia de formação?" (1999, p. 56-57). Na conclusão do artigo, o ensaísta sumariza perspectivas possíveis para o encaminhamento desse debate. Duas delas são especialmente sugestivas para a revisão dos juízos a respeito da formação brasileira surgidos na recepção crítica recente de Grande sertão: veredas. Primeiro, a hipótese de que essa idéia/ideal reduz-se a miragem, aspiração sem respaldo no atual concerto global. O andamento da história inviabilizou o projeto passado; visto hoje, o contraste entre anseios e resultados atestaria a ilusão da ambição. "A nação não vai se formar, as suas partes vão se desligar umas das outras, o setor

\footnotetext{
${ }^{2}$ Para uma reflexão nesse sentido que leva em conta um contexto nacional bem recente, ver o artigo Por que ler um clássico? - Formação da literatura brasileira em tempos difíceis (ALVES, 2005).
} 
'avançado' da sociedade brasileira já se integrou à dinâmica mais moderna da ordem internacional e deixará cair o resto”. Essa possibilidade para o rumo das coisas, no extremo, conduziria ao abandono de qualquer empenho formativo. Porém, pondera Schwarz na segunda de suas hipóteses, em alguma medida, a formação concluída de uma esfera como a literatura pode funcionar como elemento de congregação contra a barbárie. Mesmo sem corresponder à organicidade social, a unidade cultural formada entre nós (no caso, o sistema literário), proporciona algum sentido de todo, de algo em comum que "faz parte interior de todos nós que nos ocupamos do assunto, e também de muitos outros que não se ocupam dele". No mínimo, é alguma coisa "que continua dizendo que isso aqui é um todo e que é preciso lhe dar um futuro", contribui para assinalar alguma dimensão de comunidade (SCHWARZ, 1999, p. 57). Mas deve ser encarada com espírito realista - nem desprezada, nem superdimensionada -, pois está à mercê das pressões contrárias da economia mundial, cuja tendência dissociadora empurra em direção oposta à qualquer integração.

Tendo em vista esse campo de problemas, vamos à matéria crítica acumulada em torno de Grande sertão: veredas.

\section{Formação na medida do possível}

Em O mundo misturado, Davi Arrigucci avalia o livro de Rosa como "forma mesclada do romance de formação com outras modalidades de narrativa". Investigando nexos entre essa mescla e "o processo histórico-social que rege a realidade também misturada do sertão rosiano" (1994, p. 7). O termo formação, aí, não remete diretamente à tradição dos estudos sobre o Brasil a que nos referimos acima, mas à categoria literária do Bildungsroman - a partir da qual o ensaísta procura especificar o modo como o livro formaliza a dinâmica própria da experiência moderna no país. Na perspectiva desse ensaio, imbricam-se o referencial haurido das obras e da teoria relacionadas ao romance de formação e o legado dos estudos da formação brasileira (imbricação que ocorre também, de outro modo e mais explícita, no livro de Willi Bolle comentado adiante).

Arrigucci investe na descrição da arquitetura narrativa de Grande sertão: veredas, explicando-a como resultante da conjugação entre dois paradigmas - o romance de formação erudito e a tradição oral vigorosa no universo sertanejo. A seu ver, essa "mistura peculiar que define a singularidade do livro, intrinsecamente relacionada ao mundo misturado que tanto 
desconcerta esse narrador" (1994, p. 7), figura um processo de esclarecimento à brasileira. É sobre esta figuração que Arrigucci reflete. Não é difícil enxergar nessa aproximação entre o romance e a dinâmica da vida nacional o ponto de fuga naquele ideal europeu de civilização que Paulo Arantes assinalou na idéia de formação nacional entre nós.

Operando com a dialética entre gênero e História, o autor de $\mathrm{O}$ mundo misturado argumenta o seguinte. Elocução lírica, dimensão trágica, motivos e procedimentos épicos, tradição literária popular e erudita encontram-se amalgamados em Grande sertão: veredas. De saída, arma-se o quadro do narrador tradicional descrito por Walter Benjamin - a narrativa de Riobaldo começa com causos diversos, refere-se a andanças de um passado aventureiro e sintetiza um saber obtido no curso delas. Acontece que, além de a narração ocorrer em situação dialógica, na qual há um interlocutor urbano, o suposto narrador oral tem o gosto de especular, mais próprio do sujeito esclarecido pelo conhecimento letrado: "as interrogações que formula sobre o sentido de sua experiência configuram a pergunta pelo sentido da vida típica do romance burguês, voltado para os significados da experiência individual no espaço moderno do trabalho e da cidade capitalista" (ARRIGUCCI, 1994, p. 19). Os questionamentos enunciados pelo ex-jagunço, ou deixados implícitos em sua fala poética, emergem na interseção entre a ética arraigada numa comunidade "arcaica" (sertaneja) e a sensibilidade individualista da era burguesa. Se, de um lado, as inquietações são expressas por meio de casos exemplares, se sintetizam-se na imagem mítica do demônio, por outro lado, no fluxo do relato, "o enredo narrativo se traduz no discurso intelectual" - "o mythos se faz logos" num paradoxal processo de esclarecimento. A figura do narrador guarda traços da tradição épica oral, mas o relato de suas aventuras transborda os moldes dessa tradição, pois a sabedoria prática não chega a conferir sentido ao sofrido drama amoroso que perpassa a trajetória do protagonista de ponta a ponta - do encontro com o Menino na infância à morte de Diadorim. Esse passado, vivido num mundo onde o mito é recurso explicativo da ordem das coisas, impele o narrador à busca de esclarecimento sobre a existência, investimento próprio do individualismo urbano. Na forja da narrativa fingidamente oral, Riobaldo se faz herói problemático de romance moderno - ou, nos termos de Arrigucci, herói problemático de romance de formação (1994, p. 17-20). O paradoxo reside no fato de o empenho urbano e burguês de esclarecimento emergir da travessia de "uma região em princípio atrasada, imersa 
em outros tempos", o que "define um dos aspectos fundamentais da obra e nos leva ao coração da mescla, fazendo ressaltar suas articulações profundas com o contexto histórico-social do sertão (e do País) a que remete" (1994, p. 20).

O problema que ora se coloca é, pois, compreender como se dá a sutura entre as formas que vêm da tradição dos narradores anônimos da épica oral sertaneja (...) e o nascimento de uma forma da sociedade urbana moderna - o romance - que renasce em pleno interior do Brasil, de dentro do arcaico que é o mar do sertão, como se de repente, se refizesse em nosso meio a história de um gênero decisivo para a modernidade, brotando de um outro tempo. A questão é, pois, ainda entender a forma mesclada de um livro em que diversas temporalidades narrativas se misturam, correspondendo ao mundo misturado que é a nossa própria realidade. (ARRIGUCCI, 1994, p. 24).

A conclusão a respeito da mistura de formas em Grande sertão: veredas, principia com a constatação de que o romance de Guimarães Rosa "parece repetir e desenvolver em enredo narrativo o mesmo esquema da dialética do esclarecimento que Adorno e Horkheimer apontaram já no interior da epopéia homérica. 'Desencantar o mundo é destruir o animismo"' (ARRIGUCCI, 1994, p. 28). Não é outro o propósito do narrador - sertanejo com algum letramento que no passado procurou o Demônio para fazer um pacto, que não tem certeza se comprometeu-se ou não com o Mal e que, do início ao fim de sua fala, procura negar a existência do Maligno e confirmar, com a corroboração do interlocutor, a validade de sua hipótese: "Que o Diabo não existe. Pois não? (...) Nonada. O diabo não há! É o que eu digo, se for... Existe é homem humano. Travessia” (ROSA, 1986, p. 538). Apesar da hesitação contida nesse trecho final - "Pois não?", "se for" -, o crítico sublinha "a objetividade do mundo desencantado" percorrido pelo "desterrado transcendental" que é o "herói problemático e demoníaco do romance", "homem moderno, descentrado e sem volta a uma verdadeira casa", sem perspectiva de uma transcendência apaziguadora das inquietações. Parece positivo o saldo da dialética do esclarecimento dramatizada na mescla de formas em que a representação do sertão se faz mundo percorrido por um herói problemático: da leitura do "grande livro", resta a imagem do homem humano, "esclarecido e reconciliado, na medida do possível" (ARRIGUCCI, 1994, p. 29). 
Apresentada como esclarecimento individual bem sucedido, a formação de Riobaldo perde uma dimensão negativa que também a constitui. A trajetória de nosso herói comporta a percepção de que a razão instrumentalizada serve à dominação aniquiladora, ao cultivo de novas mitologias e barbáries - e jagunço letrado se vale disso em várias ocasiões. "Pontaria, o senhor concorde, é um talento todo, na idéia." (ROSA, 1986, p. 139). É significativo que, afora a morte de Diadorim, nenhum episódio da atuação tremendamente arbitrária de Riobaldo como chefe do bando seja comentado mais detidamente em $\mathrm{O}$ mundo misturado. Seu percurso aparece como trajetória individual dignificada, cuja contraparte negativa estaria justificada pelos resultados no plano da consciência. Ressalta-se mais o lado exemplar, o componente edificante da perspectiva pela qual é encarada a matéria de experiência relatada do que aquilo que há, nas atitudes do protagonista-narrador, de contraditório em relação aos valores esclarecidos que ele aprendeu a prezar tanto. A expressão que encerra o texto crítico - "na medida do possível" - evoca aquele contentamento de possibilidades infinitas sugerido no signo final do livro. Ao mesmo tempo assinala o caráter restritivo de um percurso rumo ao esclarecimento que é circunscrito ao plano da individualidade, descomprometido com a dimensão coletiva necessária ao ideal formativo de civilização integrada. O destino do ex-jagunço feito fazendeiro indicaria a tendência à não-formação, à situação de desagregação na qual “o setor 'avançado' da sociedade brasileira já se integrou à dinâmica mais moderna da ordem internacional e deixará cair o resto"? (SCHWARZ, 1999, p. 57).

\section{Formação na imaginação}

Na visão da cientista política Heloísa Starling, a narrativa de Riobaldo não só alegoriza problemas de base na formação do Brasil moderno - os percalços de nossa experiência política - como também acena com a possibilidades esperançosas de superá-los. De seu ângulo, o projeto literário de Guimarães Rosa, incluindo a proposta de releitura intensa do país, convidando o leitor à "imaginação do possível”, esboça veredas que poderiam convergir para a construção de uma outra sociabilidade a partir das "possibilidades ainda latentes de uma determinada realidade" (2006). Na tese Lembranças do Brasil, a formulação ficcional aparece como trabalho de resgate do passado que alegoriza (e assim ilumina) a dinâmica das relações sociais e de poder na ordem republicana brasileira. Pelo efeito de esclarecimento dos problemas, 
o livro funcionaria como sugestão de orientações na busca de alternativas atuais de transformação. Isso ocorre porque a ficção evidencia certos nós em nossa formação política - sobretudo, "a raiz autoritária, violenta ou paternalista, e o caráter fortemente manipulatório que vem sustentando o processo de incorporação dos indivíduos ao sistema político brasileiro" (1999, p. 20), a armação da cena republicana como "regime da liberdade e da expansão da igualdade e consolidada sobre um mínimo de participação política e um máximo de exclusão popular” (1999, p. 177).

O problema de fundo constatado pelo ficcionista seria a "existência de um vazio original instituinte da história do Brasil”, inscrito no "mapa alegórico" que é sertão por meio de três perspectivas: "a da fundação de uma comunidade política; a da inserção dessa comunidade no cenário agudamente contemporâneo de uma comunidade inconclusa; e (...) a perspectiva da oportunidade de um povo, como o nosso, construir uma identidade comum" (STARLING, 2006). A formação da esfera política na república brasileira é descrita como uma sucessão de tentativas malogradas de consolidação de um todo dotado de organicidade, tentativas alegorizadas pelas atuações dos sucessivos chefes jagunços (Medeiro Vaz, Joca Ramiro, Zé Bebelo e o próprio Riobaldo). Eis, em síntese, os principais passos da interpretação de Heloísa Starling.

A destruição das propriedades da família por Medeiro Vaz é lida como ruptura com o privatismo do poder vigente no sertão, em prol da construção de um espaço público. Cena de fundação da esfera política, mas ato fundador inconcluso, que não se completou na forma de "um ponto de mobilização e convivência entre os moradores do Sertão, orientado para além de suas condições de segurança e sobrevivência ou de seus apetites e interesses particulares" (STARLING, 1999, p. 55). Na seqüência, Joca Ramiro, ao instituir o tribunal para julgar Zé Bebelo, lida com a tarefa moderna que é consolidar o exercício da liberdade política, mas seu gesto também é marcada pelo signo do "inacabamento constitutivo", pois se a encenação de julgamento parece supor a igualdade (poder de decisão pelo voto), não se supera a desigualdade entre comandantes e comandados, a palavra final cabe ao supremo chefe (STARLING, 1999, p. 91-129). O estágio seguinte nesse histórico de formação política é o projeto reformista que Zé Bebelo traz para o sertão, quando se trata de constituir "um novo corpo coletivo, necessariamente popular, comum, centralizador, homogêneo e totalizante - o projeto de construção de um 'sertão nacional'” articulado pelas promessas 
do desenvolvimento. Mais uma vez, um projeto sem conclusão, resultando apenas na fixação de uma retórica:

(...) ênfase quase obsessiva na idéia de que a promoção do crescimento econômico e a satisfação das necessidades materiais eram suficientes para viabilizar a experiência política da construção nacional, (...) a suposta possibilidade de emancipação dos miseráveis graças ao impacto súbito de um ato redentor que desfaz ou anula os efeitos igualitários da lei pelo não-reconhecimento da legitimidade do outro como um seu semelhante. (STARLING, 1999, p. 158).

Por fim, a narração atualiza a lógica de formação marcada pela intermitente fundação. Narrar é sua forma de dar futuro ao ideal interceptado pelo curso da história: “(...) para o velho Riobaldo, fundar também é uma empresa da imaginação que obriga os homens a buscarem no tempo as razões do esquecimento, os débitos da própria história (...) - caminhos em meio às ruínas, 'o beco para a liberdade se fazer"' (STARLING, 1999, p. 180). Assim, na ficção de Guimarães Rosa, a memória, a revisão da experiência problemática passada, daria margem a alguma perspectiva - imaginária - de solução perdida. Em outras palavras: a criação literária como que contém em gérmen uma indicação do estágio que teria que ser alcançado para se resolverem problemas de base na formação nacional, pois "ao reconstruir o mundo pelas palavras, sua ficção reconstruiu o Brasil para a política iluminando seus processos mais profundos: o que falta, o que está à margem e o que é necessário se fazer presente na realidade de um país que precisa, a todo custo, encontrar o próprio caminho de passagem para o moderno" (STARLING, 1999, p. 18). Tal juízo tem por pressuposto uma relação de complementaridade entre ficção, política e História ${ }^{3}$ - o que em parte explica o tom comovido com que a crítica nos apresenta a empresa narrativa de Riobaldo como refúgio de um ideal. Como Davi Arrigucci Jr., mas por outra via, Heloísa Starling afirma uma vigência restrita da idéia de formação - limitada ao plano da imaginação. Afinal, no plano da ação, o "jagunço calculista e arrivista" (DACANAL, 1988, p. 38), foi um dos "agentes da brutalidade" (CANDIDO, 2004, p. 121), compactuou com a orquestração de forças cujos problemas seu relato testemunha. Mesmo no presente da narração, a prática permanece a contradizer o ideário.

\footnotetext{
${ }^{3}$ A esse respeito, ver o início do ensaio Imagens do Brasil: Diadorim (Starling, 2006).
} 
Mas hoje, que raciocinei e penso a eito, não nem por isso não dou por baixa minha competência num fogo-e-ferro. (...) E sozinhozinho não estou, há-de-o. Pra não isso, hei coloquei redor meu minha gente. Olhe o senhor: aqui, pegado, vereda abaixo, o Paste - meeiro meu - é meu. Mais légua, se tanto, tem o Acauã, e tem o Compadre Ciril, ele e três filhos, sei que servem. (...) Deixo terra com eles, deles o que é meu é, fechamos que nem irmãos. Para que eu quero ajuntar riquezas? Estão aí, de armas areiadas. Inimigo vier, a gente cruza chamado,

ajuntamos: é hora de um bom tiroteiamento em paz, exp'rimentem ver. (ROSA, 1986, p. 15-16)

\section{Formação pela harmonização conservadora}

A correlação entre Grande sertão: veredas e formação nacional na tese $O$ Brasil de Rosa, ao contrário de reflexões como a de Heloísa Starling, não se projeta nem para o presente nem para o futuro. Atém-se aos períodos passados correspondentes ao tempo da narração e da escrita, investigando a alegorização, levada a cabo no contexto do desenvolvimentismo getulista, da "história da vida político-institucional de nossa primeira experiência republicana e numa perspectiva que poderíamos considerar conservadora”. Luiz Roncari, de saída, faz questão de esclarecer o sentido de adjetivo tão mal visto, especificando parâmetros históricos: “o 'conservador' aqui se manifestava não como uma defesa da ordem, mas como uma crítica dela e por uma outra ordem, restauradora do pai tutelar ou da autoridade que se havia perdido com a República”. Em nota, mais adiante, o autor esclarece melhor o sentido do conservadorismo com que define o ponto de vista rosiano: trata-se de espécie de visão de mundo voltada para impasses universais, "centrada mais no conflito entre civilização e costumes, ordem e desordem, no plano institucional e familiar (além do literário), levando em conta a problematicidade da ordem". A essa perspectiva corresponde, no plano da estética, a adoção do viés clássico para a estruturação da obra - o termo "clássico" entendido ao modo de Alceu Amoroso Lima: "forma compreensiva e ordenadora das tendências e forças contrárias”. (RONCARI, 2004, p. 16-29).

Ao longo de seu estudo, Roncari procura explicar o prisma pelo qual determinados assuntos da vida brasileira são refratados na figuração literária

${ }^{4}$ Logo em seguida o velho fazendeiro se desdiz, com aquele seu modo esquivo de ser e não ser: "Digo isto ao senhor, de fidúcia. Também, não vá pensar em dobro. Queremos é trabalhar, propor sossego". (ROSA, 1986, p. 16). 
produzida por Rosa até 1956 . Os fatos políticos e sociais que o crítico percebe influentes na composição não são poucos nem pouco relevantes na história do país:

(...) a miscigenação racial e o mulato; a estratificação e a hierarquia social; a organização familiar; os problemas do arrivismo e da ascensão social; a transição dos costumes senhoriais aos burgueses; a crítica ao dinheiro como sangue corrosivo do capitalismo, corruptor e dissolvente dos valores da tradição; a concepção das elites e as suas funções civilizatórias e modernizadoras; o conflito social, não apenas no âmbito da vida socioeconômica, mas também cultural; as ambigüidades geradas pelo choque entre civilização e barbárie, cultura e rusticidade, ordem e desordem; a insuficiência dos costumes tradicionais e patriarcais; e as alternativas do processo de modernização: imitação artificial do importado e ruptura com o velho ou a assimilação do novo sob o controle da tradição. (RONCARI, 2004, p. 21).

Tendo em mira tudo isso - espécie de substrato mental depositado nas entrelinhas das narrativas -, Luiz Roncari começa a análise propriamente dita dos três primeiros livros de Guimarães Rosa destacando duas filiações. Primeiro, observa que a genealogia de protagonistas como Riobaldo remonta à estirpe dos "heróis volúveis, de perfis baixos e traços satíricos ou picarescos, como Leonardo, Brás Cubas, Dom Casmurro, João Miramar, Serafim Ponte Grande e Macunaíma” (2004, p. 27). Depois, sublinha nas feições que o autor mineiro conferiu a suas personagens, a tentativa de "representar um tipo característico, quer dizer 'brasileiro', e as suas experiências e condições de formação na nossa vida social e política" (2004, p. 28). Tal representação parece-lhe coadunada com aspectos do "homem cordial" descrito por Sérgio Buarque de Holanda (Raízes do Brasil), com as teorias de Oliveira Vianna a respeito da miscigenação racial (Populações meridionais do Brasil) e com a apologia da cordialidade do mestiço feita por Gilberto Freyre (Sobrados e mucambos). A partir dessas constatações, procura esmiuçar o enfoque crítico próprio da escrita de Rosa, dirigido a hábitos mentais arraigados em nossa sociedade - "crítica das perversões de nossa formação" (RONCARI, 2004, p. 52). Vale ressaltar três movimentos interpretativos nesse sentido.

Primeiro, Roncari assinala, ao considerar a simbologia de A volta do marido pródigo (Sagarana), uma visão metafísica do destino humano que 
se conjuga à avaliação de práticas observadas no contexto brasileiro. O escritor, a seu ver, solicita ao leitor um posicionamento menos tolerante em relação à cordialidade idealizada. Se, "quando apreciamos a outra face da cordialidade, a bruta e violenta, parece que a compreendemos impassíveis, como se estivéssemos cientes da pouca liberdade e baixa consciência das ações humanas", como alternativa, o "que se pede na novela de Guimarães é que o leitor fixe o seu ponto de vista no alto", "que reveja as suas simpatias e as restabeleça a partir de valores menos pessoais e emotivos", voltando-se para "outros mais impessoais e abstratos" (2004, p. 44-45). Estão em jogo aí matizes da dinâmica entre ordem e desordem, vida pública e vida privada no Brasil, mantidos em evidência nos momentos em que o autor se concentra em Grande sertão: veredas.

Num segundo movimento, constrói-se a ponte entre Lalino, o cordial marido pródigo, e Riobaldo. A interpretação explicita então um aspecto crucial da inscrição do processo histórico nacional no romance - a trajetória pessoal do herói sintetizando e alegorizando aquela que a população brasileira teria vivido entre a Primeira República e a primeira metade da década de 1950. A hipótese central é que as tensões subjetivas manifestas no comportamento do protagonista de Grande sertão: veredas se enraízam na estrutura da sociedade sertaneja e na relação entre a época da ação e a época da narração.

Guimarães Rosa narra sobre um passado próximo, o do coronelismo da Primeira República, que está vivendo no tempo do autor uma tentativa de superação. O caráter mais geral e marcante desse período (e do herói Riobaldo, como veremos mais adiante), para Guimarães, foi o de ter sido ele carente de Pai ou um vazio entre dois grandes pais: Dom Pedro II, o tutor justo da sociedade imperial, e Getúlio Vargas, o grande chefe e "pai dos pobres". (RONCARI, 2004, p. 58).

O terceiro movimento que interessa destacar é a análise do tribunal que julga Zé Bebelo, núcleo da alegorização da experiência político-institucional brasileira no romance, contraparte pública dos direcionamentos observados antes na vida privada, por meio das relações amorosas de Riobaldo (e dos outros protagonistas criados por Rosa). A "flexibilidade da tradição e o seu processo de assimilação" em um novo costume (o fato de a ordem patriarcal perpetuar-se mesmo com a instituição de uma instância mais avançada 
do ponto de vista civilizatório, o fato de Joca Ramiro, "o Pai-Patriarca, cujo poder não era imposto, mas dado pelo carisma e pela tradição" ser "aceito pelo conjunto") daria o tom de nossa modernização conservadora, figurada também na dimensão pessoal da trajetória do herói que não se forma, mas recorre à solução arcaica para efetuar uma mudança (em si e no meio em que atua). Nas palavras de Roncari: "institucionalização de um aspecto da vida sob o patrocínio (ou a regência) dos espíritos e totens arcaicos enraizados na história (...), a mudança no sentido de seu revigoramento e fortalecimento". (2004, p. 293-303).

O processo do tribunal surgiu, por um lado, como a oportunidade de representar ao leitor, diretamente, as duas questões mais gerais e decisivas em discussão no romance: primeiro, a da formação do herói, como pode alguém se formar num universo social estratificado e sem padrões civilizatórios minimamente fixados, o que o levaria a um formar-se e deformar-se constante, num nunca se acabar; e, segundo, a da estruturação do lugar, as possibilidades e dificuldades de incorporação (Alceu Amoroso Lima diria assimilação) das instituições modernas e civilizadas num mundo rústico. (...) O que o julgamento parecia fundar era uma instituição que incorporava o costume (e vice-versa), em vez de simplesmente combatê-lo para erradicá-lo e substituí-lo por uma ordem artificial vinda de fora. (...) Entretanto, como resultado da experiência do julgamento, tudo parecia revirar e o sertão tornava-se ainda mais sertão. De alguma forma, o Brasil era ali também alegorizado, como um enorme espaço periférico, dominado por relações ásperas e arcaicas, experimentando as possibilidades de civilização. (RONCARI, 2004, p. 263-265).

Conflitos do tipo civilização x barbárie, arcaico x moderno, ordem x desordem, urbanidade $\mathrm{x}$ violência são freqüentes em interpretações que procuram revelar a visão do país em Grande sertão: veredas. Mas há uma peculiaridade digna de nota na leitura de Roncari. À diferença da maioria dos intérpretes de sua geração, não vê aí a sinalização de uma perspectiva, seja frustrada, seja estimuladora de esperança, que comporte a possibilidade de transformação democrática do país, a alternativa de um caminho para a emancipação que se desvie do conservadorismo patriarcalista. Ressalta, ao contrário, a harmonização mantenedora dos parâmetros norteadores de práticas sociais e políticas enraizadas, patrocinados por patriarcalismo e mandonismo, e apenas ajustados aos novos termos da institucionalidade. 
Na sua avaliação, a busca de um caminho, figurado na ficção, para escapar aos impasses da história brasileira teria sido guiada pelo pensamento de Alceu Amoroso Lima, em especial pelo ideal de assimilação.

"O problema da civilização brasileira é um problema de assimilação", declara o autor de Política e letras, obra que Roncari considera chave para se entender a visada de Rosa sobre a formação nacional (2004, p. 339). Contra a tendência dissociadora, os antagonismos nos âmbitos político e literário, Amoroso Lima sugere a síntese pela harmonização conservadora, uma proposta, segundo Roncari, que ganhou formulação estética na ficção do escritor mineiro - "Guimarães parece tê-lo assumido como diagnóstico e aceito a sua proposta de solução, quase como uma missão a ser cumprida pela sua obra" (2004, p. 24).

O propósito de conciliação de forças contrárias - viés clássico no plano estético, assimilação como solução apaziguadora de tensões para a construção da ordem nacional - seria portanto um aspecto estruturante da ficção em estudo. Esse ponto central no juízo de Luiz Roncari aporta alguns problemas raramente postos em evidência na recepção contemporânea do romance. Por exemplo, as implicações da idéia de clássico de Alceu Amoroso Lima - "O clássico é a verdade total (...) O clássico é uma estética senhoril" (Apud RONCARI, 2004, p. 16). No âmbito dos projetos para o país, a contraparte dessa verdade senhoril seria a salvaguarda de valores calcados nos termos da modernização conservadora. A matriz convocada por Roncari, nesse plano, é Oliveira Vianna.O seguinte trecho de Instituições políticas brasileiras, citado a propósito da cena do tribunal, deve servir para indicar a orientação que o crítico detecta na alegoria rosiana da formação sociopolítica do Brasil.

O nosso grande problema, como já disse alhures, não é acabar com as oligarquias; é transformá-las - fazendo-as passarem da sua atual condição de oligarquias broncas para uma nova condição - de oligarquias esclarecidas. Estas oligarquias esclarecidas seriam então, realmente, a expressão da única forma de democracia possível no Brasil; porque realizada na sua forma genuína, isto é, no sentido ateniense - do governo dos melhores. (Apud RONCARI, 2004, p. 317. Negritos de Roncari).

Esta seria, do ponto de vista armado em O Brasil de Rosa, a perspectiva de formação política do país que figurava no horizonte da narrativa de Riobaldo, na inclinação clássica de Grande sertão: veredas. 


\section{Formação pelo diálogo entre classes}

Desde o subtítulo de grandesertão.br, Willi Bolle anuncia qual a tese que defende: Grande sertão: veredas é o romance de formação do Brasil. A expressão que procura definir a obra ficcional conjuga propositalmente duas constelações intelectuais que balizam a análise - o cânone nacional dos ensaios de formação e o ideário romântico-alemão em torno do Bildungsroman. Da comparação com os estudos sobre a formação brasileira, o crítico conclui que o livro de Guimarães Rosa "é o mais detalhado estudo de um dos problemas cruciais do Brasil: a falta de entendimento entre a classe dominante e as classes populares, o que constitui um sério obstáculo para a verdadeira emancipação do país”. (2004, p. 9). Por outro lado, observa que a narrativa, do modo como se compõe, recupera o sentido original de "romance de formação", uma vez que o relato a respeito da formação de um indivíduo aparece comprometido com o todo social - "um projeto mais arrojado: a construção de uma cultura coletiva, incorporando as dimensões políticas da esfera pública, da cidadania e dos conflitos sociais". (2004, p. 382). É isso que estaria implicado na pesquisa formal com os meios de expressão: "um projeto de formação social, com a inclusão das camadas populares. Através do seu alter ego Riobaldo, que se movimenta no meio das falas do povo, o escritor está em contato com a oficina onde se forja a língua" (2004, p. 402).

Na avaliação de Bolle, em Grande sertão: veredas o contato entre cultura letrada e cultura não-letrada se faz de tal maneira que deixa em vislumbre, ainda hoje, uma perspectiva positiva para a efetiva emancipação do país. O romance ganha, nessa leitura, ares de exemplo utópico, solução figurada para o "problema estrutural antigo e atual do Brasil" que é "a ausência de um verdadeiro diálogo entre os donos do poder e o povo”. (2004, p. 17). As tensões graves da vida social e política nacional estariam apresentadas com um tratamento estético que se configura, ele mesmo, em promissor experimento ("laboratório") de diálogo entre classes. Por um lado, o romance lança luz sobre o modo de fabricação do discurso do poder; por outro, abre espaço de manifestação para as "falas do povo" - tudo isso graças à mediação de um narrador que transita entre ambos os pólos. Seu relato conduz ao conhecimento de fatores determinantes na história do país: na fala do narrador pactário revelam-se as artimanhas dos donos do poder, enquanto a figura de Diadorim funciona como medium para o retrato do povo. grandesertão.br debruça-se sobre essas três instâncias: discurso do poder, falas do povo e mediação. 
A relação do protagonista-narrador com a retórica do poder é analisada em dois capítulos sucessivos, dedicados ao sistema jagunço e ao significado do pacto com o demônio. A trajetória de Riobaldo em meio ao mundo jagunço, vista como percurso de iniciação política, cumpriria a função de incitar no leitor a reflexão crítica a respeito da instituição da jagunçagem - fator central para a compreensão do fenômeno da violência e do crime no país, assim como do funcionamento do sistema de poder entre nós. Num primeiro momento (do início até o trecho em que o relato passa a seguir a cronologia da vida do herói), o elemento básico é a questão moral, sobressaindo o fato de que o jagunço pode servir tanto ao Bem quanto ao Mal. No segundo estágio (correspondente ao período em que Riobaldo reside com Selorico Mendes até o início da luta contra Hermógenes e Ricardão), intercalam-se idealização cavaleiresca da vida jagunça e consciência da brutalidade jagunça experimentada tanto do lado da "situação" (o bando liderado por Zé Bebelo), quanto do da "oposição", e também em meio à luta interna desencadeada pelo assassinato de Joca Ramiro. Por fim, na última parte do enredo (período da chefia de Riobaldo), consolida-se a desidealização da vida de jagunço, prevalecendo a visão de um mundo desencantado e violento, em que a instituição da jagunçagem mostra-se imbricada com o problema social. Diante da ascensão social do protagonista, Willi Bolle pergunta-se se a história narrada é mesmo a da extinção de um jagunço ou se, pelo contrário, ela não apresenta o próprio modo como se engendra e se sustenta o sistema de poder em que se inserem os jagunços. Enfocando a instituição da jagunçagem como sistema discursivo-retórico, o romance assinalaria sua dimensão nacional e sua projeção para o presente. Trata-se de "uma representação do funcionamento atual das estruturas do país", não "um poder paralelo, mas o poder". (2004, p. 117-125).

A estratégia de Willi Bolle para apresentar o discurso da jagunçagem como sistema discursivo-retórico de tamanha abrangência é a abordagem da "relação entre o discurso da jagunçagem e o discurso mediador do narrador rosiano, que faz parte dessa estrutura, ao mesmo tempo em que se distancia criticamente dela" (2004, p. 124). Se, por um lado, Riobaldo comenta e contesta os discursos dos chefes (chamando atenção para os interesses disfarçados em suas falas), por outro lado, ele mesmo, quando chefe, passa a ser um dos porta-vozes do sistema (e, no momento da narração, busca justificar sua atitude). Isso instigaria o leitor a examinar criticamente o próprio discurso do narrador, uma vez que há, no romance, uma instância 
metanarrativa, situada "acima dos interesses de Riobaldo como dono do poder", operando sob forma de suas observações autocríticas e das "montagens", "comandadas pelo próprio Guimarães Rosa", as quais põem em contraste com a retórica dos poderosos outros registros discursivos (2004, p. 132-134). Dois níveis do discurso de Riobaldo interessam nesse ponto.

Primeiro, a prática do discurso do poder, exercitado na ocasião em que o protagonista ocupou o posto de chefe de jagunços. No contato com Zé Bebelo, Riobaldo havia assimilado a "arte de lutar com palavras", o "know-how dos donos do poder", que inclui a capacidade de se amoldar às transformações da situação política. A habilidade mais decisiva que desenvolve então, e que colabora para sua promoção de raso jagunço a chefe do bando é um "procedimento-chave no discurso do poder": a dissimulação - empregada para a tomada da chefia, para o recrutamento compulsório de mão-de-obra guerreira e para lidar com a contestação de alguns homens que decidem desertar do bando. Especialmente nos dois últimos casos, Bolle identifica uma função genérica que a camuflagem retórica desempenha na estrutura de poder do país: "a retórica da simulação é usada para fazer com que o sistema jagunço apareça como instrumento por excelência para resolver os problemas sociais", ou para encobri-los. Em sua avaliação, com a montagem de fragmentos de discurso do poder realizada por Guimarães Rosa, com a visão desses exercícios da "arte de enganar o povo", "o leitor acaba obtendo uma imagem da estrutura política e social vigente” (2004, p. 174-181).

O segundo nível discursivo destacado é a narração da história para o interlocutor. Lembrando os termos da retórica de Quintiliano, Bolle observa que, se o discurso do chefe Riobaldo é dissimulado e demagógico (ars fallendi), o do narrador Riobaldo é dialético, conjugando a arte da persuasão ("primado dado à construção da credibilidade", manifestação de dono do poder) à "ciência de falar bem" ("a busca da verdade e da justiça, que caracteriza o homem justo e bom"). Diante desse "narrador dialético", o ponto crítico seria "como avaliar essa auto-acusação e confissão do narrador pactário" (2004, p. 184-188). Eis a avaliação do autor de grandesertão.br:

O fato de o narrador ser pactário é também um estratagema para justificar que ele passe a trair o sistema dominante e a revelar seus segredos. Em vez de denunciar ou legitimar, ele mostra como se fabricam discursos de denúncia e de legitimação. (...) A capacidade do narrador rosiano de tornar transparente a função diabólica da linguagem é, no sentido original da palavra, uma 
qualidade luciférica. Esboça-se assim uma afinidade eletiva entre a arte de narrar de Guimarães Rosa e o satanismo de Baudelaire, o poeta no auge do capitalismo, cuja posição foi caracterizada por Walter Benjamin nestes termos: “(...) Era um agente secreto - um agente da insatisfação secreta de sua classe com a sua própria dominação." (BOLLE, 2004, p. 194). ${ }^{5}$

Vistas as questões relativas ao discurso dos donos do poder, passa-se à segunda instância que o crítico considera integrante da rede discursiva tramada em Grande sertão: veredas - as "falas do povo". Observando as funções que Diadorim desempenha na narrativa, Bolle afirma que essa figura, decisiva na trajetória do jagunço Riobaldo e no encaminhamento da narração, é também expressão da paixão artística, “o medium, através do qual o romancista expressa seu amor pelo povo sertanejo" - "o trabalho de luto do narrador pela pessoa amada faz com que se construa, através de uma linguagem inovadora, um símile da vida, [...] a história do povo" (2004, p. 224-225).

Diadorim é associada "à dificuldade dos letrados brasileiros de retratar esse desconhecido maior que é o povo" (BOLLE, 2004, p. 25). Num primeiro momento, funciona como ponte que traz Riobaldo para o meio dos jagunços; posteriormente, conforme o herói avança na carreira do poder, afastando-se dos antigos companheiros, ela permanece cada vez mais integrada a esse meio, determinando, na economia do romance, a mediação entre a perspectiva dos donos do poder, com a qual Riobaldo compactuara, e a experiência dos sertanejos pobres. Nesse ponto, a interpretação de Willi Bolle diverge totalmente da de Luiz Roncari. Ambos encaram Diadorim como parâmetro que desperta em Riobaldo certa consciência de sua condição social, mas enquanto Bolle procura identificá-la com a população pobre, segundo Roncari ela incorpora para o protagonista, desde o primeiro encontro, tudo aquilo de que ele se ressentia - falta de recursos materiais, de capacidade de decisão, de aptidão para o mando -, tudo o que tem que obter para desvencilhar-se dos percalços de filho da plebe rural. (RONCARI, 2004, p. 61-70).

Willi Bolle descreve a representação do povo em dois movimentos comparativos que se sucedem. O primeiro pauta-se pela confrontação do

${ }^{5} \mathrm{O}$ trecho de Benjamin encontra-se no ensaio Paris do Segundo Império e foi traduzido por Willi Bolle diretamente da edição alemã. 
romance com os ensaios sobre a formação nacional. O objetivo aí é ressaltar o caráter de invenção subjacente à representação do povo e da nação em Grande sertão: veredas, a partir da hipótese de que o retrato do Brasil elaborado pelo escritor tem seu foco no problema da nação dilacerada pela falta de diálogo entre as classes sociais. Seguindo uma constatação de Antonio Candido registrada em Jagunços mineiros de Cláudio a Guimarães Rosa - "paridade entre o dilaceramento do narrador e o dilaceramento do mundo" (CANDIDO, 2004, p. 121) -, Bolle procura mostrar que "o dilaceramento do narrador e seu modo despedaçado de narrar são a forma artístico-científica através da qual Grande Sertão: Veredas expressa o dilaceramento da nação" (BOLLE, 2004, p. 264). O segundo movimento corresponde à parte final de grandesertão.br. Pondo-se à prova a hipótese de que o romance se faz história criptografada do Brasil, trechos da fala em que Riobaldo confronta Zé Bebelo para tomar a chefia do bando são associados a marcos históricos nos quais ocorreu mudança de regime (proclamação da independência, instituição da república, Revolução de 1930, implantação do Estado Novo, o momento do nacional-desenvolvimentismo). Esses períodos relacionados ao livro (os primeiros por serem referências na memória do narrador-protagonista ou em sua trajetória, os dois últimos por dizerem respeito ao período em que a obra foi escrita), são evocados para especificar o modo como a elaboração ficcional revê as transformações dos conceitos de povo e nação ao longo da história do país. A conclusão é uma síntese do valor de conhecimento sobre o Brasil que Bolle atribui à estética de Guimarães Rosa:

Os donos do poder jogam com a incongruência entre "povo" e "nação", ou seja, com a nação dilacerada, para administrar os conflitos. A constituição do Estado democrático burguês é, no sentido literal da palavra, uma ficção fundadora. Por isso mesmo, uma ficção com alto potencial reflexivo, como Grande sertão: veredas, é particularmente apta a revelar aquele caráter ficcional. (BOLLE, 2004, p. 373).

Por fim, no último capítulo de grandesertão.br, trechos da narrativa que registram "falas do povo" são contrapostas à elocução do protagonista-narrador que as reproduz. Em todos os casos, Willi Bolle sublinha o fato de que, em meio ao relato do velho fazendeiro Riobaldo se manifestam, escapando à distorção ideológica, vozes da classe a que ele antes pertenceu, 
manifestações de sertanejos pobres que permitem "montar um retrato do Brasil articulado pelo próprio povo" (2004, p. 438). Esse encerramento da análise é acompanhado de um juízo positivo a respeito do potencial político do romance. Como Heloísa Starling, Bolle vê sugeridas na articulação ficcional perspectivas positivas para problemas do país. Se em Lembranças do Brasil isto é posto de modo genérico, em grandesertão.br ganha a concretude de práticas (notadamente, as educacionais) que o crítico encara como gérmen para se alcançar um utópico ponto no futuro. Esse é um aspecto central na interpretação de Willi Bolle, um pressuposto em sua interpretação do "retrato do Brasil" figurado na forma ficcional: a relação entre cultura letrada e cultura não-letrada se faz de tal maneira que sinaliza, ainda hoje, uma perspectiva de continuidade para a formação nacional. Bolle parece convicto de que, na sofisticada configuração ficcional elaborada pelo erudito Guimarães Rosa, as "falas do povo" encontram-se integradas com o discurso do poder, numa, digamos, harmonia dissonante.

\section{Formação supressiva}

O otimismo das expectativas com as quais grandesertão.br acena - diálogo de classes conduzindo à efetiva formação da nação - não tem nada do tom de impasse com o qual José Antônio Pasta Jr. caracteriza o "regime peculiar ao livro - o da formação como supressão". Enquanto Willi Bolle parte da percepção de que o "povo" está integrado como dono da voz na escrita de Rosa, Pasta vê nela a expressão de uma "contradição insolúvel e central que singulariza o Brasil". Não se trata, para Pasta, apenas da desigualdade que separa os donos do poder das camadas pobres, mas do fato de que, aqui, "a alteridade - ou a autonomia - do outro seja ao mesmo tempo reconhecida e negada, pressuposta e inconcebível". Enquanto Bolle aposta no diálogo como perspectiva de uma síntese final para a formação brasileira, caminho para a superação de problemas que perpassam nossa história, Pasta refere-se às tensões que marcam nossa experiência como algo que "não conhece superação ou síntese, mas apenas o entrematar-se dos princípios em oposição e, assim, o conflito sempre renascente". Seu ensaio O romance de Rosa - temas do Grande sertão e do Brasil parece antecipar um reparo à avaliação do romance enunciada em grandesertão.br: "Nos seus meios de caminho, travessias, limiares, passagens, não é raro que o filósofo encontre a autêntica mediação, onde não há senão o puro limite; que o crítico literário encontre a síntese que supera e transforma, onde vige a má infinidade" (PASTA Jr., 1999, p. 67-69). 
Pasta argumenta que o próprio princípio organizador da obra, aquilo que "responde pelo conjunto de sua estruturação formal", define também seu regime de leitura. E toca num ponto nevrálgico: o fato de, diante da grande obra estética, os intérpretes tenderem a se colocar em atitude de reverência, a referendar as soluções que vêem engendradas no texto ficcional. Essa constatação é o ponto de partida para a hipótese de que a tendência geral a enxergar na obra "virtudes exclusivamente positivas" não corresponde a um mero "acidente da recepção". O ensaísta argumenta que a identificação dos intérpretes com o texto, fato que compromete o "gesto de relativização que implica toda crítica", "manifesta de maneira decisiva o modo de ser mais íntimo da obra", o "princípio de hibridização", assim descrito: "vigência simultânea de dois regimes de relação sujeito-objeto um que supõe a distinção entre sujeito e objeto ou, se se quiser, o mesmo e o outro, e um segundo que supõe a indistinção de ambos". Observando a constituição da consciência do narrador, Pasta procura demonstrar que esse princípio de passagem do mesmo ao outro define um movimento de "formação supressiva" do narrador-protagonista, que repercute também na leitura. Vincado por uma série de contradições ("livre e dependente; homem de lei e de mando, de contrato e de pacto; letrado e iletrado - moderno e arcaico"), Riobaldo o tempo todo "se 'forma' passando no seu outro". Lembrando a lógica que o próprio narrador enuncia - tudo é e não é - o crítico nota que, na medida em que ele se constitui como "mutação contínua", "vem a ser no e pelo movimento mesmo em que deixa de ser: ele se forma suprimindo-se". A estrutura da recepção do livro é determinada pela mesma dinâmica: "O Grande sertão, também ao leitor ele o forma suprimindo-o, isto é, simultaneamente ele o concebe como alteridade e o suprime enquanto tal"; somos absorvidos em "um mundo que simultaneamente nos constitui e nos abole, baralhando os limites que nos separam dele". Se o narrador pede a todo momento a opinião de seu interlocutor, numa atitude que parece salvaguardar os limites da alteridade, ao mesmo tempo, a voz desse outro é sistematicamente suprimida, encontra-se amalgamada à narração, de tal modo que o leitor acaba por se converter em "uma espécie de duplo do narrador". Com isso, do ponto de vista da recepção, o romance de Rosa se apresenta como uma aporia, "parece esperar que a crítica, renunciando ao seu enleio nessa duplicidade hipnótica" resolva "o dilema insolúvel de sucumbir a um encantamento e ao mesmo tempo denunciá-lo" (1999, p. 62-69). O ensaio alerta para o 
fato de que questões de longo alcance estão implicadas nesse hibridismo que "constitui uma espécie de marca de nascença do próprio país".

Nação colonial e pós-colonial, o Brasil já surge na órbita do capital e como empresa dele, mas se estabelece e evolui com base na utilização maciça, praticamente exclusiva e multissecular, do trabalho escravo. Essa contradição de base forma uma espécie de enigma sociológico que as ciências humanas permanecem a interrogar, entre nós. (...) Ao longo de séculos, e de um modo que nunca superaram completamente seja a Independência, sejam as sucessivas modernizações conservadoras, o Brasil praticou a junção contraditória de formas de relações interpessoais e sociais que supõem a independência ou a autonomia do indivíduo e sua dependência pessoal direta. (PASTA Jr., 1999, p. 67).

A contribuição que o ensaísta procura dar para a solução desse enigma é a especificação do estatuto da formação supressiva, motor paradoxal de Grande sertão: veredas. Sua formulação é complexa e dá margem a muita discussão. Aqui, caberá apenas registrá-la, para assinalar sua originalidade no que diz respeito à correlação entre a forma do romance e a formação brasileira.

$\mathrm{Na}$ conclusão do artigo, propõe-se uma questão que parece, à vista do conjunto de críticas visto aqui, ultrapassada: "a polêmica quanto a se saber se, enfim, em Rosa, o salto do sertão para o mundo é imediato ou se passa por uma mediação essencial, que é o Brasil". A resposta de Pasta é: "ambas as posições estão certas e erradas ao mesmo tempo", dado o regime de formação supressiva que rege o livro, que põe a mediação no e pelo mesmo movimento em que a subtrai (1999, p. 70). É como se a possibilidade de reconhecer na forma literária uma totalização da formação nacional permanecesse arredia, sempre escapando por entre os dedos de quem tenta enunciá-la na interpretação. A origem do problema, da perspectiva do ensaio, é a má infinitude de um processo formativo que "só conhece a ultrapassagem que não supera, e as oscilações intermináveis” (1999, p. 69).

A trajetória de Riobaldo tem essa marca, de uma "unificação infinitamente problemática". Suas sucessivas mudanças de condição e de posição na guerra, fugas, oscilações entre pólos respondem à “junção inextricável, em um mesmo princípio, de movência obrigatória e fixidez inamovível, de metamorfose contínua e pura repetição". Ao longo de todo o relato, ele se faz outro, permanecendo o mesmo. "No passado do narrador, no presente 
da narração - nenhuma superação -, o mesmo dilema se põe e repõe inteiro, irredutível: como o mesmo pode ser outro?” (1999, p. 63). Pasta lembra: "No Brasil, o outro é da ordem da iminência" (1999, p. 68), "o fato de que a alteridade - ou a autonomia - do outro seja ao mesmo tempo reconhecida e negada, pressuposta e inconcebível, constituem em profundidade o imaginário paradoxal das relações interpessoais e intersubjetivas" (1999, p. 67).

É bem singular a avaliação de José Antônio Pasta Jr. Tanto que, na contramão da tendência a ler o signo do infinito, que figura como paradoxal ponto final da narrativa, como abertura para o possível, o crítico enxerga nele uma marca negativa: "o escoar-se indefinido do que não sabe nem pode acabar" (1999, p. 65). Emblema de uma sociedade sem perspectiva de completar a integração de suas partes?

\section{Referências Bibliográficas}

ALVES, Luis Alberto Nogueira. Por que ler um clássico? Formação da literatura brasileira em tempos difíceis. In: BUENO, André (org.). Literatura e sociedade: narrativa, poesia, cinema, teatro e canção popular. Rio de Janeiro: 7Letras, 2006, p. 263-279.

ARANTES, Paulo. Providências de um crítico na periferia do capitalismo. In: ARANTES, Otília Beatriz Fiori. Sentido da formação: três estudos sobre Antonio Candido, Gilda de Mello e Souza e Lúcio Costa. Petrópolis: Paz e Terra, 1997, p. 7-66.

ARRIGUCCI JR., Davi. O mundo misturado: romance e experiência em Guimarães Rosa. Novos estudos Cebrap, nº 40, p. 7-29, nov. 1994.

BOLLE, Willi. grandesertão.br: o romance de formação do Brasil. São Paulo: Duas Cidades/Ed. 34, 2004.

CANDIDO, Antonio. Jagunços mineiros de Cláudio a Guimarães Rosa. In: Vários escritos. $4^{\mathrm{a}}$ ed. Reorganizada pelo autor. São Paulo: Duas Cidades/ Rio de Janeiro: Ouro sobre Azul, 2004, p. 99-124.

. Formação da literature brasileira. Rio de Janeiro: Ouro sobre Azul, 2006.

DACANAL, José Hildebrando. A epopéia de Riobaldo. In: Nova narrativa épica no Brasil. 2. ed. Porto Alegre: Mercado Aberto, 1988, p. 9-39. 
GALVÃO, Walnice Nogueira. As formas do falso: um estudo sobre a ambigüidade no Grande sertão: veredas. São Paulo: Perspectiva, 1986.

PASTA JR., José Antonio. Temas do Grande sertão e do Brasil. Novos Estudos Cebrap, no 55, p. 61-70, nov. 1999.

RONCARI, Luiz. O Brasil de Rosa: mito e história no universo rosiano: o amor e o poder. São Paulo: Editora UNESP, 2004.

ROSA, João Guimarães. Grande sertão: veredas. Nova Fronteira: Rio de Janeiro, 1986.

SCHWARZ, Roberto. Os sete fôlegos de um livro. In: Seqüências brasileiras: ensaios. São Paulo: Companhia das Letras, 1999, p. 46-58.

STARLING, Heloísa. Outras conversas sobre os jeitos do Brasil. Suplemento Literário de Minas Gerais - Arquivo Guimarães Rosa, n 19, p. 14-16, nov. 1996.

. Lembranças do Brasil: teoria política, história e ficção em Grande sertão: veredas. Rio de Janeiro: Revam/UCAM/IUPERJ, 1999.

Imagens do Brasil: Diadorim. Semear. Rio de Janeiro, no 5, Departamento de Letras/Cátedra Padre António Vieira da Estudos Portugueses/Pontifícia Universidade Católica, 2001. Disponível em: <http://www. letras.puc-rio.br/Catedra/revista/5Sem_12.html>. Acesso em: 28 abr. 2006. Não paginado. 